GESDAV

Original Research

\title{
Ethno botany and antimicrobial perspective of Spices and Honey against Candida albicans
}

\begin{abstract}
Kothai Seshathri ${ }^{1}$, Getahun Befirdu ${ }^{2}$
Meenakshi Agribusiness and Extension Service, III Cross, Indian Bank Colony, Trichy, Tamil Nadu, India Department of Animal Science, Jimma University College of Agriculture and Veterinary Medicine, Jimma, Ethiopia.

Received: April 15, 2013

Accepted: June 26, 2013

Published Online: July 20, 2013

DOI : 10.5455/jice.20130626044910

Corresponding Author:

Kothai Seshathri,

Meenakshi Agribusiness and Extension

Service, No.69, III Cross, Indian Bank

Colony, Trichy - 620021, Tamil Nadu, India

kothaiseshathri@yahoo.co.in

Keywords: Ethno botany, Candida albicans, spices, honey, Trachyspermum copticum

Abstract

Aim: In spite of obsessive use of spices in every Ethiopian meal, little has been investigated on the utilization of Ethiopian spices as a cure for oral opportunistic infections. Therefore, the aim was to identify spices used in Ethiopian food through ethno botanical survey and study their antifungal activity against Candida albicans.

Method: Ethno botanical survey of the selected Kebeles of Jimma, Ethiopia was conducted using a semi structured questionnaire from October 2006 to November 2007. Antifungal nature of the spices and combination of spices and honey were evaluated by agar well diffusion assay from September 2008 to July 2010.

Result: Ethno botanical survey indicated fourteen species of spices and honey play a major role in Ethiopian food \& beverages. Single plant extract of Trachyspermum copticum showed highest activity against $C$. albicans. The same plant showed antagonistic effect when combined with brown and white honey. Cinamomum zeylanicum showed highest synergistic effect with both brown \& white honey when compared to Allium ursenum, Cuminum cyminum, Nigella sativa, Rosemarinus officinalis and Lippia adoensis

Conclusion: Thus spices used in Ethiopian food could be a preventive as well as a cure for oral candidiasis caused by C. albicans.
\end{abstract}

(C) 2013 GESDAV

\section{INTRODUCTION}

The burden of developing and under developed countries is tinted with day to day increase in endless list of opportunistic infections due to HIV/AIDS, diabetes, chemotherapy for cancer and contraceptive use. Immunosuppression and intolerance to antibiotics were the major constraints in managing oral opportunistic infections. Today, the introduction of highly active antiretroviral therapy (HAART) has dramatically reduced the incidence of opportunistic infections among HIV-positive people and Oropharyngeal candidiasis (OPC) with a shift in the spectrum of Candida species and remains the most frequent HIV-associated oral lesion in most developing countries, as well as underdeveloped countries like Ethiopia [1]. However, access to HAART is still limited in Ethiopia [2]. At this junction, herbal remedies can restrain the situation and sustain an immediate cure for the exploited. In addition, malevolent side effects, drug resistance and recurrence of infection will also be taken care of. Further, Ethno botanical survey of selected Kebeles of Jimma, Ethiopia, revealed obsessive use of spices and honey [3]. Herbs and spices have been used for their antimicrobial properties in preventing food deterioration and pathogenic diseases [4]. Previous researchers have confirmed the antifungal activity of honey against C. albicans [5], [6], [7] and Fluconazole resistant

C. albicans isolated from the oral cavity of AIDS patients [8]. Similarly, Spices of different parts of the world were studied for their anti-fungal activity. However, very little work has been reported so far 
regarding the pharmacological properties of aromatic spices and herbs used in the Ethiopian traditional spiced food preparations [9]. Thus, an attempt was made to analyze the antifungal nature of selected spices and honey against $C$. albicans to suggest an immediate solution to the affected in Ethiopia as well as across the globe.

\section{MATERIALS AND METHODS}

\section{Ethno botanical survey}

The selected informants were interviewed repeatedly and the information regarding the usage of plants in day to day activities was collected through questionnaire based ethno botanical survey from October 2006 to November 2007. The data indicated that fourteen species of plants viz., Afromomum angustifolium, Allium ursenum, Brassica oleraceae, Curcuma longa, Cuminum cyminum, Cinamomum zeylanicum, Lippia adoensis, Ocimum basilicum, Trachyspermum copticum, Nigella sativa, Rosemarinus officinalis, Ruta chalepensis, Thymus schimperi and Zingiber officinale were used as spice [3] and the same were used for the current study.

\section{Collection and extraction of spices and spice mixture}

Plant parts used as spices identified through ethno botanical survey were collected from vendors of Jimma Market, extracted and stored in a refrigerator. Working concentration of $100 \mathrm{mg} / \mathrm{ml}$ was prepared by reconstitution in Dimethyl sulfoxide (DMSO).

Traditionally prepared Ethiopian chilli spice mixture comprised of Afromomum angustifolium, Allium ursenum, Cuminum cyminum, Lippia adoensis, Nigella sativa, Ocimum basilicum, Ruta chalepensis, Thymus schimperi and Ethiopian chilli was extracted with 70\% ethanol and the oily substance obtained was stored in the refrigerator at $4^{0} \mathrm{C}$.

\section{Honey}

Un-processed raw honey was collected from Coffee estate in Jimma and working concentration was prepared by dissolving in known volume of water.

\section{Combination of spices and honey}

Spice extracts were mixed with brown/white honey at 1: 1 concentration

\section{Test organism}

The referral strain, C.albicans ATTCC 10231 was obtained from Ethiopian Health and Nutrition Research Institute (EHNRI), was used in this experiment.

\section{Antimicrobial activity}

Antimicrobial activity was determined by agar well diffusion method [10]. Fluconazole as positive control and DMSO as negative control were included in all the experimental plates and each experiment was done in triplicates.

Agar well diffusion assay was repeated with spices and honey mixture. The effect of combination of plants extracts and honey was calculated using the following formula [11].

Calculated zone size $=$ sum of zone size of both extracts $/ 2$

If,

1. Observed zone size $=$ calculated zone size then the effect will be additive

2. Observed zone size $>$ calculated zone size then the effect will be synergistic

3. Observed zone size $<$ calculated zone size then the effect will be antagonistic

\section{Minimum inhibitory concentration (MIC)}

Modified micro dilution method [12] was employed to determine Minimum inhibitory concentration (MIC) of single spice plant extracts as well as combination of spices and honey. Instead of standard broth, PPG1\% was used in the experiment. Colour change from red to yellow indicated fungal growth.

\section{RESULTS}

The results of this study documented low incidence of C.albicans among the selected informants (Table 1) of the study area. Ethno botanical survey of the Kebeles (2, 3 \& 5) revealed that fourteen species of plants were used as spice in Ethiopian food, beverages and medicine. Generally, the spice plants (Table 2) were collected from home gardens (Fig. 1) and sold in the market (Fig. 2). A.ursenum, R.chalepensis, R.officinalis, and Z.officinalis were sold in fresh form, whereas A.angustifolium and T.schimperi are sold as fresh and in dried form. Rest of spices chosen in this study were sold in dried form only. Generally, all the spices were sold in the local market along with vegetables, butter and fruits. These plants belonged to six families and many of them were from Lamiaceae family. Specific part of the plant like leaf, stem, bark, bulb, rhizome, inflorescence and seed were used as spice. Seed was found to be the most used part followed by leaf. Spices were used in all Ethiopian sauces and dried Ocimum and Lippia leaves were added to butter to impart flavour (Table 2). Spices used in chilli spice mixture were roasted and coarsely ground at 
home (Fig. 3) \& then milled in the machine and used in all traditional Ethiopian food preparations especially in all sauces. Crushed seeds of B.oleraceae were wrapped in a cloth and smeared over the pan used for making injera (fermented pan cake) (Fig. 4).

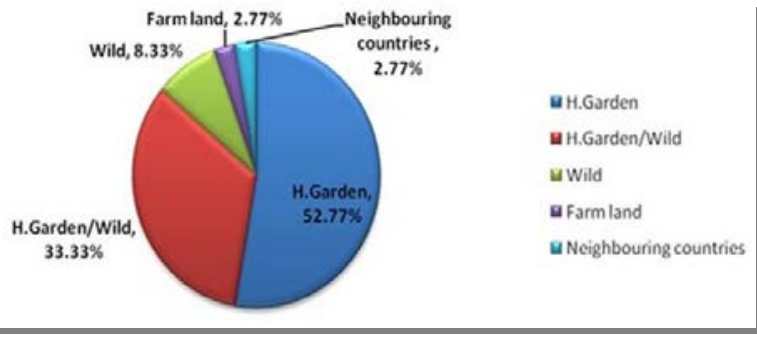

Fig. 1. Place of collection of medicinal plants by the herb sellers

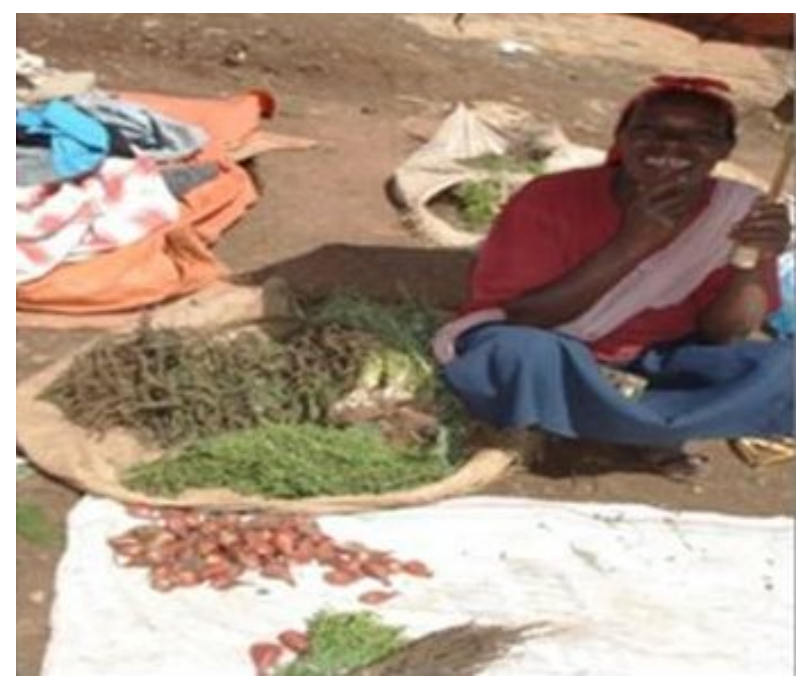

Fig. 2. Spice seller in Jimma market

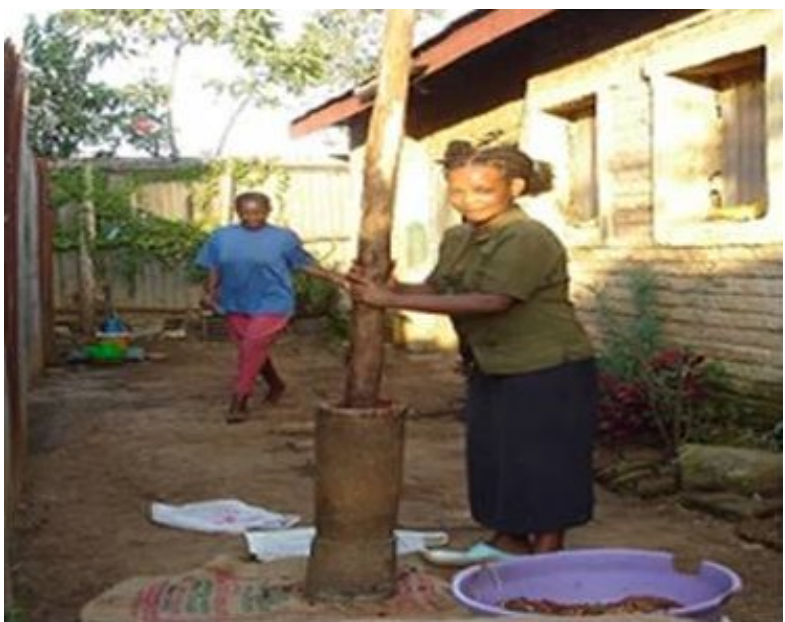

Fig. 3. Pounding of spices with chilli

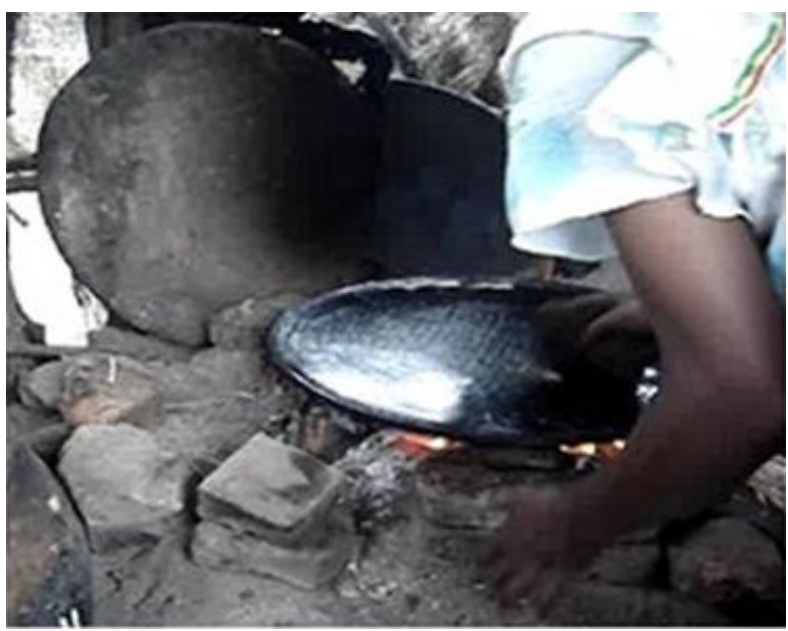

Fig. 4. Crushed seeds of $B$. oleraceae applied on the injera making pan

Table 1. Details of Samples Collected

\begin{tabular}{llll}
\hline No & $\begin{array}{l}\text { Clinical } \\
\text { symptom }\end{array}$ & $\begin{array}{l}\text { No. of samples } \\
\text { Collected N (\%) }\end{array}$ & $\begin{array}{l}\text { No. of Samples } \\
\text { positive for } \\
\text { C. albicans } \\
\mathbf{N}(\%)\end{array}$ \\
\hline 1. & Gum infection & $45(20.73)$ & - \\
\hline 2. & Halitosis & $43(19.81)$ & $2(00.92)$ \\
\hline 3. & Tonsillitis & $43(19.81)$ & $3(01.38)$ \\
\hline 4. & Tooth pain & $43(19.81)$ & - \\
\hline 5. & Throat pain & $43(19.81)$ & - \\
\hline Total & & $217(99.97)$ & $5(2.30)$ \\
\hline
\end{tabular}


Journal of Intercultural Ethnopharmacology 2013; 2(2):73-80

Table 2. Spices used by the informants of selected Kebeles of Jimma - Ethiopia

\begin{tabular}{|c|c|c|c|c|c|c|}
\hline No & Local name & Scientific name & Family & $\begin{array}{l}\text { Part(s) of } \\
\text { the plant used }\end{array}$ & Use in food & $\begin{array}{l}\text { Ethnomedicinal } \\
\text { use }\end{array}$ \\
\hline 1. & Besobila & Ocimum basilicum $L$. & Lamiaceae & Leaf & Sauce & Fever \\
\hline 2. & $\begin{array}{l}\text { Nech } \\
\text { Shinkurit }\end{array}$ & Allium ursinum. $L$ & Liliaceae & Bulb & Sauce & $\begin{array}{l}\text { Malaria, tooth pain, } \\
\text { fever }\end{array}$ \\
\hline 3. & Gingibil & Zingiber officinale Rose. & Zingiberaceae & Rhizome & Sauce & $\begin{array}{l}\text { Breathing difficulty, } \\
\text { cough }\end{array}$ \\
\hline 4. & Gomenzer & $\begin{array}{l}\text { Brassica oleraceae } \\
\text { L.var.botrytis }\end{array}$ & Brassicaceae & Seed & Greasing injera pan & $\begin{array}{l}\text { High body } \\
\text { temperature }\end{array}$ \\
\hline 5. & Kereffa & Cinnamomum zeylanicum & "Lauraceae & Bark & Tea & Itching \\
\hline 6. & Korarima & $\begin{array}{l}\text { Aframomum angustifolium } \\
\text { Sonn }\end{array}$ & Zingiberaceae & Seed & Sauce, milk & Chest congestion \\
\hline 7. & Kosaret & Lippia adoensis, Forsk. & Verbanaceae & Inflorescence/leaf & $\begin{array}{l}\text { Clarification of butter } \\
\& \text { sauce }\end{array}$ & Fever \\
\hline 8. & Nech Azimud & Trachyspermum Copticum L & Apiaceae & Seed & $\begin{array}{l}\text { Meat, chicken sauce, } \\
\text { bread }\end{array}$ & Ulcer \\
\hline 9. & Rosemary & Rosemarinus officinalis.L & Lamiaceae & Leaf & Meat sauce & $\begin{array}{l}\text { High body } \\
\text { temperature }\end{array}$ \\
\hline 10. & Ten Adam & Ruta chalepensis $L$. & Rutaceae & Seed & Sauce & Evil eye \\
\hline 11. & Tiqur Azimud & Nigella sativa & Ranunculaceae & Seed & $\begin{array}{l}\text { Meat, chicken sauce, } \\
\text { bread }\end{array}$ & Gastritis, ulcer \\
\hline 12. & Tosigni & Thymus schimperi & Lamiaceae & Leaf & Sauce, tea & Fever \\
\hline 13. & Erid & Curcuma longa $L$. & Zingiberaceae & Rhizome & Sauce & - \\
\hline 14. & Zeera & Cuminum cyminum & Apiaceae & Seed & Sauce & - \\
\hline 15. & $\begin{array}{l}\text { 'mum } \\
\text { Chilli spice } \\
\text { mixture }\end{array}$ & $\begin{array}{l}\text { 1,2,6,7,8,10,11,12, } 14 \text { + } \\
\text { Berbere }\end{array}$ & - & - & All sauces & - \\
\hline
\end{tabular}

Antifungal activity of spices against C. albicans summarized in Fig. 5 indicated that $T$. copticum was highly reactive followed by $C$. zeylanicum, $N$. sativa and $R$. chalepensis. The pathogen was resistant to $A$. angustifolium, $B$. oleraceae, $C$. longa, L. adoensis, R. officinalis, and Z. officinale. Rest of plants selected in this study showed moderate activity against $C$. albicans. The resistance of the pathogen towards the spice plants used in the study was measured and found that T. copticum showed the lowest MIC followed by Chilli spice mixture (Fig 6).

\section{Antimicrobial activity of spices against C.albicans}

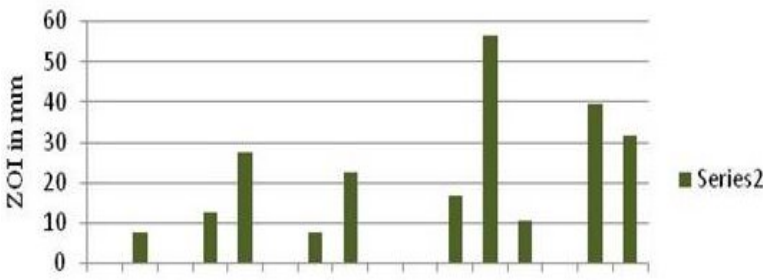

$\begin{array}{llllllllllll}1 & 2 & 3 & 4 & 5 & 6 & 7 & 8 & 9 & 1011 & 121314 & 1516\end{array}$

Spices, spice mix \& +ve control
The results summarized in Fig. 7 clearly indicated that the combination of spices and brown honey produced different levels of interaction; additive, synergistic, antagonistic or no activity. Antifungal activity of eight spices namely A. ursenum, C. cyminum, C. zeylanicum, C. longa, N. sativa, L.adoensis, R. officinalis and $R$. chalepensis was increased synergistically when combined with brown honey. T. copticum, T. schimperi and chilli spice mixture showed antagonistic activity when combined with brown honey, i.e. observed values were lesser than the expected value of the same combination. Though the activity of T.copticum was reduced by combining with brown honey, i.e. the ZOI produced by the combination of T.copticum and brown honey was higher than the rest of the spice plants used in this study. There was no antifungal activity in case of A. angustifolium B. Oleraceae, O. basilicum and Z. officinale, and their activity was also not enhanced by the addition of brown honey i.e. the compounds present in these spice plants were not synergistic, antagonistic nor additive. 


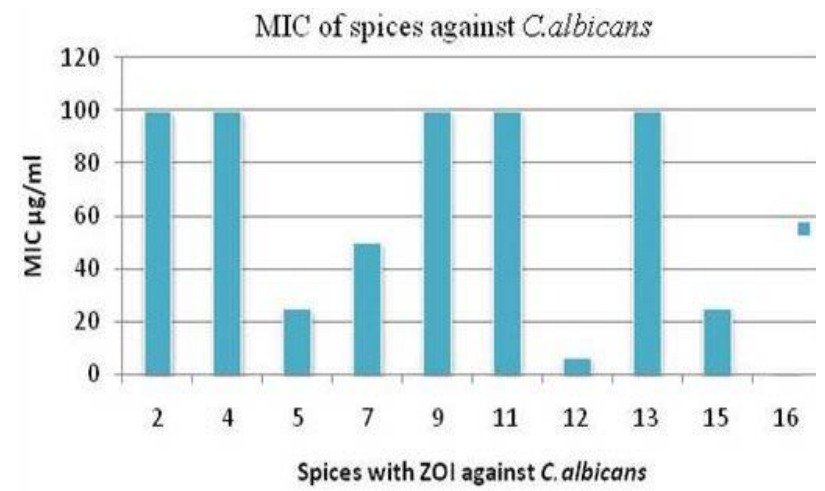

Fig. 6. MIC of spices against $C$. albicans

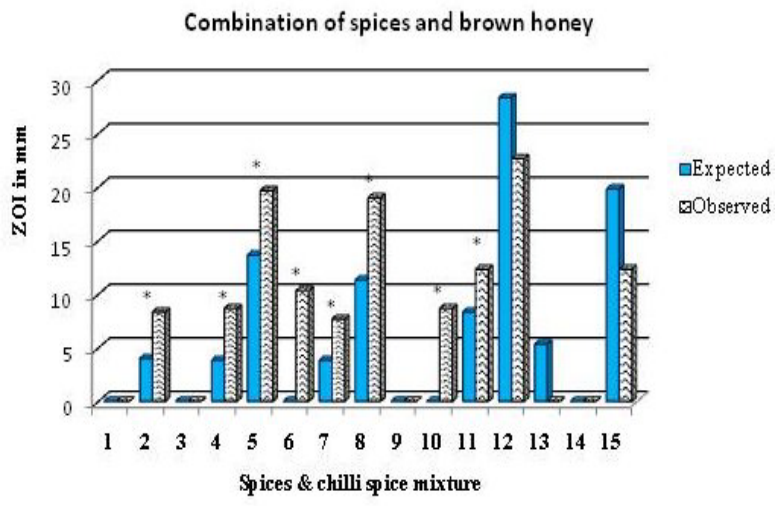

Fig. 7. Combination of spices and brown honey

R. chalepensis, Trachyspermum copticum and chilli spice mixture worked antagonistically with white honey whereas A. ursenum, C. cyminum, C. zeylanicum, C. longa, $\quad N$. sativa, L.adoensis, $R$. officinalis and Thymus schimperi were synergistic. C. albicans was resistant to combination of white honey with Afromomum angustifolium, Brassica oleraceae, Curcuma longa, Ocimum basilicum, and Zingiber officinale (Fig. 8).

\section{DISCUSSIONS}

Ethno botany of spices of Jimma

Indigenous people possess immense knowledge of their environments [13], and they are skilled in careful selection and proper utilisation of plants in food and beverages as preventive and protective action against several diseases. Therefore, in recent years, ethno botanical and traditional uses of natural compounds especially of plant origin received much attention as they are well tested for their efficacy and generally believed to be safe for human use [14]. Cultivation and use of spices, herbs and medicinal and other essential oil bearing plants is not new to Ethiopia. It is as old as the crop themselves and its history can be traced back to the reign of Queen Sheeba (ca 992B.C).

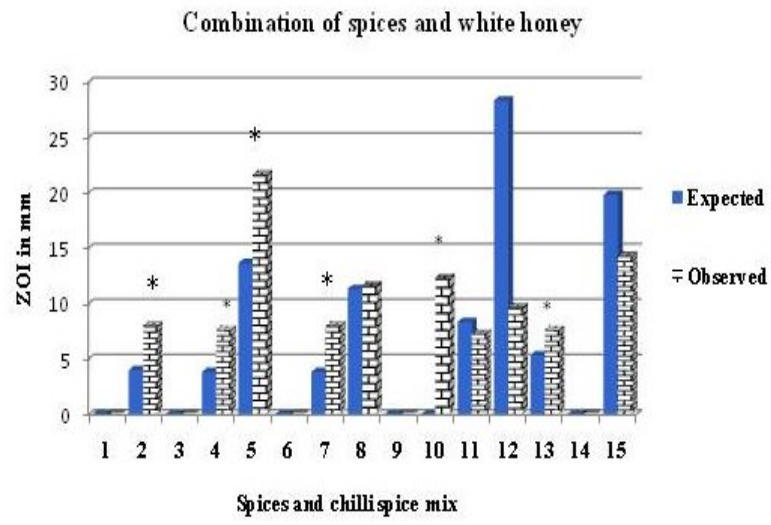

Fig. 8. Combination of spices and white honey

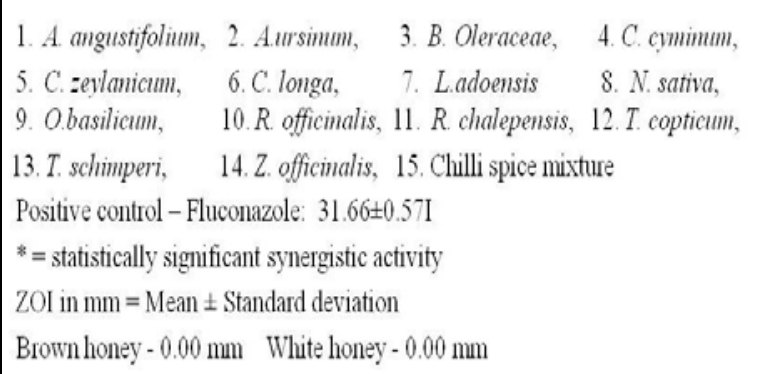

Fig. 9. Foot note for Fig. 5, 6, 7 \& 8

The informants of this study were willing to share their cultural knowledge of plants used in food and beverages without any bias. This enabled the authors to find out the similarities in Ethiopian and Indian scenario regarding spice usage in food. For example, in India, leaves of Moringa oleifera or Murraya koenigii (curry leaf) were added to clarify and impart flavour to butter, which was similar to the addition of Ocimum leaves for the same reason in Ethiopia. It is also known as Al-Rehan (In Arabic) which has received a great deal of attention over the past decades around the world [15]. 


\section{Antifungal activity of spices}

Addition of some spices to foods could not only impart flavour and pungent stimuli but also would provide antimicrobial property [5]. Although many plants have been investigated for their antifungal activity against $C$. albicans, the search is still on to find long term prevention and cure with medicinal herbs available in each locality. The results of this study correlated with the previous researchers who proved that the growth of C. albicans was controlled by $A$. ursenum [16] $C$. zeylanicum [17], C. cyminum [18], N. sativa [19] [20] and $R$. chalepensis [21] and contradicted with Hussien, (2011), in case of T. schimperi [9].

According to Rasooli, (2008), ajowan oil contained thymol (37.2\%), and p-cymene (32.3\%) [22], whereas, Chialva, (1993) reported (61\%) thymol, (15.6\%) pcymene and (11.9\%) $\gamma$-terpinene [23]. Therefore, it is evident that the constituents of a plant greatly differ with geographical location and thereby in their bioactivities. Cox, (2001) found that particularly $\gamma$ terpinene in ajowan oil was effective against $C$. albicans [24] and Hammer 1999 recorded the lowest MIC value of $0.03 \% \mathrm{v} / \mathrm{v}$ for thymol oil against $C$. albicans [25] and Giordani 2004 further insists that Thyme is a potent antifungal, being of particular benefit in oral candidiasis [26]. In addition, ethno botanical survey of this study indicated that whole seeds of $T$. copticum were used in the preparation of bread and in sauces. Thus T. copticum could have directly or indirectly inhibited $C$. albicans and resulted in low incidence of oral thrush caused by $C$. albicans.

\section{Honey}

Antimicrobial activity of honey is primarily due to hydrogen peroxide generated by the action of an enzyme that bees add to the nectar, but there are some floral sources which provide additional antimicrobial compounds [27]. Though many researchers have confirmed that honey inhibit the growth of $C$. albicans, results of Kothai, (2012) revealed that Honey collected from Jimma Market was not effective against $C$. albicans [28] and correlated with the results of Moussa, (2012) who found that C. albicans was resistant to all concentrations $(10,30,50 \& 70) \%$ of undiluted honey samples collected in Algeria [29].

\section{Combination of Spices and honey}

Secondary metabolites and volatile compounds in $A$. ursenum, C. cyminum, C. zeylanicum, $N$. sativa, $R$. officinalis and $L$. adoensis, might have worked synergistically with both brown and white honey and produced a broad spectrum antifungal activity. There was no report on the use of these spices in combination with honey. Further exploration will lead to an efficient herbal remedy for oral Candida infection.

\section{Chilli spice mixture}

A spice mixture with a combination of Cinnamon, clove and ginger, showed higher activity against $C$. albicans than the individual effect [5]. Similarly, Ethiopian chilli spice mixture exhibited high antifungal activity than the individual effect of most of the spices chosen for this study. Chilli spice mixture used in this study was prepared traditionally in which Afromomum angustifolium, Allium ursenum, Cuminum cyminum, Ocimum basilicum, Lippia adoensis, Nigella sativa, Ruta chalepensis, Thymus schimperi and Ethiopian chilli were combined in a specific quantity and the exact reason was un-known. Exuberant use of this mix in everyday dishes could be also another reason for low incidence of $C$. albicans which needs further exploration.

\section{Synergistic activity}

High degree of synergistic activity due to the wide variety of organic compounds present in either single plant or multi plant extracts could be a major reason for low incidence of $C$. albicans among the inhabitants irrespective of their HIV status. Thus, the burden in using the synthetic antifungal agents which bring serious side effects, drug resistance and resurgence of Candida infection could be effectively managed with natural food based therapy.

\section{CONCLUSION}

Plant based cure through spiced food which are consumed in a locality and within their cultural context might be one of the simple way to meet the immediate health care need of the economically downtrodden in Ethiopia as well as across the globe. Unknowingly the use of spices have already reduced the burden of oral candidiasis caused C.albicans and the current study has scientifically validated the folkloric usage of Ethiopian spices which further deepen the association between the plants and inhabitants. Therefore, this study insists on regular use of Ethiopian spices may prevent oral candidiasis caused by $C$. albiacns and may alleviate the same where access to HAART is limited. As the effect is dose dependent, further research on the standardisation on the quantity of spice used in each food is necessary to get the desired effect against the fore said pathogen.

\section{ACKNOWLEDGEMENT}

The authors thank everyone who helped them to conduct the survey, collection of spices and in translation of Amharic language into English. Thanks to Jimma University College of Agriculture and Veterinary medicine for availing the Library, Internet 
and Laboratory facilities. The authors also thank Mr. Kacha Hunde and Mr. Abatemam in identification of plants.

\section{REFERENCES}

1. Diro E, Feleke Y, Guteta S, Fekade D, Neway M. Assessment of risk behaviours and factors associated with oral and peri-oral lesions in adult HIV patients at Tikur Anbessa Specialized Hospital, Addis Ababa, Ethiopia. Ethiopian Journal of Health Development. 2009; 22(2): 180-186.

2. Mulu A, Kassu A, Anagaw B, Moges B, Gelaw A, Alemayehu M, et al. Frequent detection of 'azole' resistant Candida species among late presenting AIDS patients in northwest Ethiopia. BMC Infectious Diseases. 2013; 13(1): 82.

3. Kothai S. Ethnobotany and antimicrobial activity of medicinal plants of Jimma, Ethiopia. Tiruchirappalli: Bharathidasan University, India. 2012.

4. Al-Wabel NA. Antimicrobial and antioxidant properties of spices. Bulletin of Pharmaceutical Sciences. 2007; 30(1): 81-87.

5. El-Kholie EM, Abdelreheem M, Khader SA. Inhibitory effect of some spices powder and its oils on pathogenic microorganisms in liquid media. African Journal of Microbiology Research. 2012; 6(16): 3791-3796.

6. Saeed S, Tariq P. Antimicrobial activities of Emblica officinalis and Coriandrum sativum against gram positive bacteria and Candida albicans. Pakistan Journal of Botany. 2007; 39(3): 913-917.

7. Jeddar A, Kharsany A, Ramsaroop UG, Bhamjee A, Haffejee IE, Moosa A. The antibacterial action of honey An in vitro study. South African Medical Journal. 1985; 67(7): 257-258.

8. Mulu A, Diro E, Tekleselassie H, Belyhun Y, Anagaw B, Alemayehu M, et al. Effect of Ethiopian multiflora honey on fluconazole-resistant Candida species isolated from the oral cavity of AIDS patients. International Journal of STD \& AIDS. 2010; 21(11): 741.

9. Hussien J, Teshale C, Mohamrned J. Assessment of the Antimicrobial Effects of Some Ethiopian Aromatic Spice and Herb Hydrosols. International Journal of Pharmacology. 2011; 7(5): 635-640.

10. Perez C, Pauli M, Bazerque P. An antibiotic assay by the agar-well diffusion method. Acta Biologica Et Medica Experimentalis. 1990; 15: 113-115.

11. Mujeeb UR, Shereen G, Ejaz EO, Umed AS, Irfan A. Affectivity of Zataria multiflora Boiss Alcoholic extracts against bacteria. Libyan Agriculture Research Centre Journal International. 2010; 1(3): 147-152.

12. Samie A, Tambani T, Harshfield E, Green E, Ramalivhana JN, Bessong PO. Antifungal activities of selected Venda medicinal plants against Candida albicans, Candida krusei and Cryptococcus neoformans isolated from South African AIDS patients. African Journal of Biotechnology. 2010; 9(20): 2965-2976.

13. Sekar S, Mariappan S. Usage of traditional fermented products by Indian rural folks and IPR. Indian Journal of Traditional Knowledge. 2007; 6(1): 111-120.

14. Saneja A, Sharma C, Aneja KR, Pahwa R. Gymnema Sylvestre (Gurmar): A Review. Der Pharmacia Lettre. 2010; 2(1): 275-284.

15. Amjad K. Antimicrobial activity of ethanolic extracts of Ocimum basilicum leaf from Saudi Arabia. Biotechnology. 2013. 1-4.

16. Bagiu RV, Vlaicu B, Butnariu m. Chemical composition and in vitro antifungal activity screening of the allium ursinum L.(Liliaceae). International Journal of Molecular Sciences. 2012; 13(2): 1426-1436.

17. Das CT, Das R, Mohanty R. Antifungal activity of some medicinal plants on clinically isolated Candida tropicalis. Trends in Biosciences. 2009; 2(2): 7-10.

18. Singh R, Singh AK, Soam A, Shahi SK. Antifungal screening of various spice extracts on azole resistant strains of Candida. Current Discovery. 2013; 2(1): 46-51.

19. Suthar M, Patel PN, Shah TG, Patel RK. In vitro Screening of Nigella sativa seeds for antifungal activity. International Journal of Pharmaceutical and Applied Sciences. 2012; 1(2): 84-91.

20. Bita A, Rosu AF, Calina D, Rosu L, Zlatian O, Dindere $\mathrm{C}$, et al. An alternative treatment for Candida infections with Nigella sativa extracts. European Journal of Hospital Pharmacy: Science and Practice. 2012; 19(2): 162.

21. Merghache S, Hamza M, Bendahou M, Tabti B. Chemical Composition and Antimicrobial Activity of Ruta chalepensis L. Essential Oil from Algeria. Asian Journal of Chemistry. 2008; 20(4): 2989-2996.

22. Rasooli I, Fakoor MH, Yadegarinia D, Gachkar L, Allameh A, Rezaei MB. Antimycotoxigenic characteristics of Rosmarinus officinalis and Trachyspermum copticum L. essential oils. International Journal of Food Microbiology. 2008; 122: 135-139.

23. Chialva F, Monguzzi F, Manitto P, Akgul A. Essential oil constituents of Trachyspermum copticum (L.) Link fruits. Journal of Essential Oil Research. 1993; 5(1): 105-106.

24. Cox S, Mann CM, Markham JL. Interactions between components of the essential oil of Melaleuca alternifolia. Journal of Applied Microbiology. 2001; 91: 492-497.

25. Hammer KA, Carson CF, Riley TV. Antimicrobial activity of essential oils and other plant extracts. Journal of Applied Microbiology. 1999; 86: 985-990.

26. Giordani R, Regli P, Kaloustian J, Mikail C, Abou L, Portugal $\mathrm{H}$. Antifungal effect of various essential oils against Candida albicans. Potentiation of antifungal action of amphotericin B by essential oil from Thymus vulgaris. Phytotherapy Research. 2004; 18: 990-995.

27. Molan PC. The role of honey in the management of 
wounds. Journal of Wound Care. 1999; 8(8): 415-418.

28. Kothai S. Antimicrobial properties of Ethiopian chewing sticks against Candida albicans. Journal of Applied Pharmaceutical Science. 2012; 2(1): 45-50.
29. Moussa A, Noureddine D, Saad A, Abdelmelek M, Abdelkader B. Antifungal activity of four honeys of different types from Algeria against pathogenic yeast: Candida albicans and Rhodotorula sp. Asian Pacific Journal of Tropical Biomedicine. 2012; 2(7): 554-557.

This is an open access article licensed under the terms of the Creative Commons Attribution Non-Commercial License which permits unrestricted, non-commercial use, distribution and reproduction in any medium, provided the work is properly cited. 